107

\title{
デジタルホログラフイック顕微鏡を用いた純チタン試験片の \\ 引張りに伴う表面形状変化 \\ Change in Surface Profile of Pure Titanium Specimen during Tension \\ Using Digital Holographic Microscope
}

\begin{abstract}
○学 高橋 孝輔 (岡山大院), 正 多田 直哉（岡山大自然），正 内田 真 (岡山大自然)
\end{abstract}
Kousuke TAKAHASHI, Okayama University, 3-1-1 Tsushima-naka, Kita-ku, Okayama, 700-8530, Japan

Naoya TADA, Okayama University, 3-1-1 Tsushima-naka, Kita-ku, Okayama, 700-8530, Japan

Makoto UCHIDA, Okayama University, 3-1-1 Tsushima-naka, Kita-ku, Okayama, 700-8530, Japan

Key Words: Pure Titanium, Surface Profile, Digital Height Correlation Method, Digital Holographic Microscope

\section{1. 緒 言}

多結晶金属材料は, 結晶方位や大きさの異なる多数の結晶 粒で構成されており，不均一な弾塑性変形挙動を示す。特に 材料表面に位置する結晶粒に関しては，この変形不均一性が 表面の凹凸や高度分布の変化となって現れる。一方，近年， デジタルホログラフィック顕微鏡が開発され, 材料表面にお ける比較的広い範囲の高度分布が高精度かつ短時間で取得 できるようになり, 半導体や MEMS 関連の分野で利用され ている．そこで本研究では，多結晶純チタン試験片に対して 引張り試験を行い, 同顕微鏡により取得した材料表面の高度 分布に対してデジタル高度相関法 ${ }^{1)}$ を適用し, 材料表面の各 結晶粒における平均高度増分について検討を行った。

\section{2. 試 験 方 法}

\section{1 試験片}

試験素材には，厚さ $1 \mathrm{~mm}$ ，純度 $99.5 \mathrm{wt} \%$ の業用純チタン 板材を使用した。 この板材からワイヤーカット放電加工で図 1 に示寸形状・寸法の試験片を切り出し, その後, 表面を 1500 番までの耐水研磨紙を用いて研磨を行った。 また, 残留応力 除去および結晶粒径の調整のため, 1143K, 2 時間保持の条件 で真空焼鈍を行い, 結晶粒の識別を容易にするために電解研 磨および化学腐食を行った。

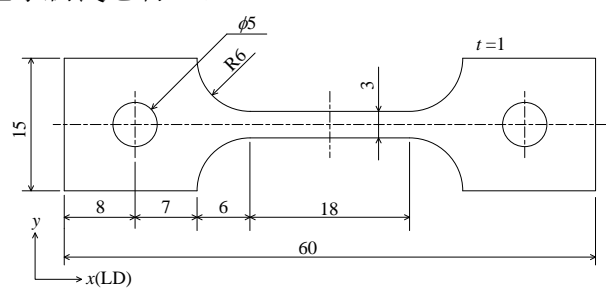

Fig.1 Shape and size of tensile specimen $(\mathrm{mm})$

\section{2 デジタルホログラフィック顕微鏡}

デジタルホログラフィック顕微鏡（Digital Holographic Microscope, DHM : スイス Lyncee Tec 社, 反射型 DHM R1100）はホログラムを利用して試験片表面の 3D 画像を高 分解能で測定できる. ホログラムはビデオカメラ経由で PC に保存された後, 位相と振幅信号に分けられ, この 2 つの信 号を再構築することにより, リアルタイムで 3D 画像が得ら れる. 1 枚の画像取得に要する時間は最短 $1 \mu \mathrm{s}$ であり, 同顕 微鏡の垂直および水平分解能はそれぞれ $0.2 \mathrm{~nm}, 2845 \mathrm{~nm}$ (対 物レンズ 5 倍）である.

\section{3 引張り試験}

引張り試験には定格容量 $2 \mathrm{kN}$ の引張・圧縮小型材料試験機 （（株）井元製作所）を用いた。試験片に段階的に引張り負 荷を与え, 各段階で DHM を用いて表面の高度測定を行った。 これを試験片表面において多数のすべり線が観察されるま で続け, 除荷した. 各段階で与えた負荷荷重を表 1 に示す.

Table 1 Load at each step

\begin{tabular}{|c|c|c|c|c|c|c|}
\hline Step & 0th & 1 st & 2nd & 3rd & 4th & 5 th \\
\hline Load $P(\mathrm{~N})$ & 0 & 211 & 423 & 476 & 529 & 556 \\
\hline & \begin{tabular}{|c|c|c|c|c|c|}
\hline 6 th & 7 th & 8th & 9th & 10 th & 11 th \\
\cline { 2 - 8 } 582 & 608 & 635 & 661 & 794 & 0 \\
\hline
\end{tabular}
\end{tabular}

\section{4 デジタル高度相関法}

撮影したデジタル輝度画像を用いて材料表面上の同一点 を探索する手法にデジタル画像相関法 ${ }^{2)}$ がある. 本手法は撮 影画素の 1 画素以下の分解能で同一点探索やひずみ評価が可 能なため, 最近では, 材料試験においても用いられている. 本研究では, 輝度画像データを DHMにより取得した高度分 布に置き換えて同一点探索を行うデジタル高度相関法を用 いて, 段階的な引張り変形前後における同一領域を特定し, その領域内の高度分布変化について検討した。

\section{5 平均高度}

多結晶金属材料の不均一変形は, 結晶粒間の高度差となっ て現れると考えられる. そこで, 本研究では対象領域内全体 の平均高度を基準とし, その基準に対して各結晶粒中心部の 高度が負荷とともにどのように変化するかについて検討し た. 各結晶粒の高度は, その結晶粒の中心に位置する $21 \times 21$ pixels（結晶粒が小さい場合は $11 \times 11$ pixels）の正方形領域の 平均高度 $h_{\mathrm{m}}$ とした。 $h_{\mathrm{m}}$ は次式より求めた。

$$
h_{\mathrm{m}}=\frac{1}{n^{2}} \sum_{i=1}^{n} \sum_{j=1}^{n} h\left(x_{i}, y_{j}\right)
$$

ここで， $n$ は正方形領域の縦軸（試験片長手方向に垂直）ま たは横軸（試験片長手方向）のピクセル数であり， $\left(x_{i}, y_{j}\right)$ は 各ピクセルの位置, $h$ はその位置での高度である，位置の特 定は，前述のデジタル高度相関法を用いて行った。 
3. 試 験 結 果

\section{1 試験片表面の様子}

システム金属顕微鏡 BX41M-LED（オリンパス（株））か ら得られた変形後の観察領域の画像を図 2 に示寸. 図中では, 測定対象となる結晶粒の結晶粒界をわかりやすく実線で示 し，評価する結晶粒に番号を与えている．図からわかるよう に, 引張り負荷後の試験片表面にはすべり線が発生しており, その発生状況も結晶粒毎に異なっている.

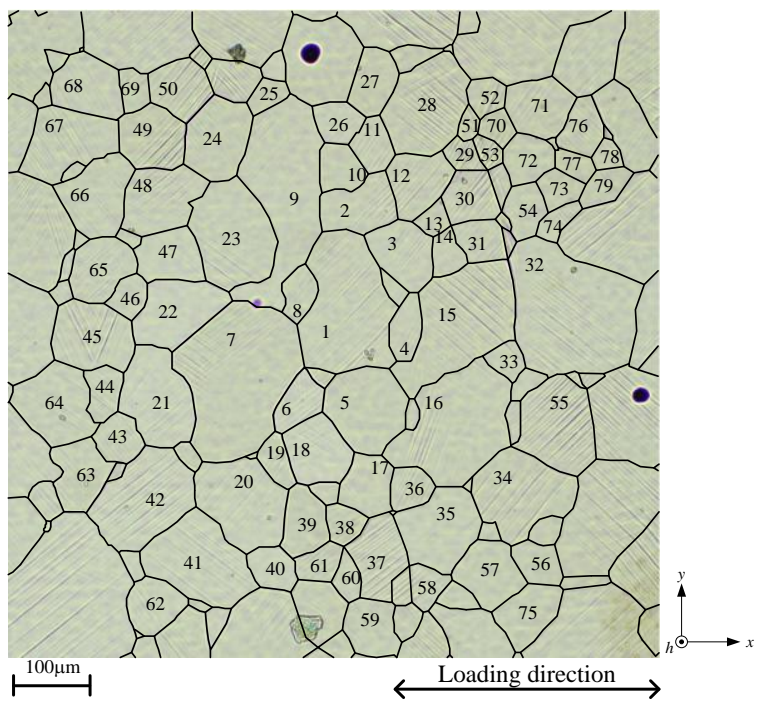

Fig.2 Specimen surface after tensile test

\section{2 平均高度増分}

図 3 に各結晶粒の平均高度増分, 図 4 に単位荷重あたりの 平均高度増分の変化を示す. 図 4 では平均高度 $h_{\mathrm{m}}$ から負荷 前の平均高度 $h_{\mathrm{m} 0}$ を引いた值を, 荷重 $P$ で除している。両図 では，結晶粒 1 から結晶粒 20 までのデータを示している. 図 4 から, 引張り負荷が 476(N) 時に単位荷重あたりの平均 高度が大きく変化していることが確認でき, その前段階の荷 重である 423(N) より大きな荷重で塑性変形が始まったと考 えられる。

図 5 に 2 つの弾性変形段階間 $(P=0(\mathrm{~N})$ から $211(\mathrm{~N})$ と $P=0(\mathrm{~N})$ から 423(N)）における平均高度増分の関係, 図 6 に 弾性変形段階 $(P=211(\mathrm{~N})$ 加 $5423(\mathrm{~N}))$ と塑性変形段階 $(P=608(\mathrm{~N})$ から $793(\mathrm{~N}))$ における平均高度増分の関係を示す. 図 6 では, 縦軸のスケールが横軸のスケールの 10 倍となっ ていることに注意を要する。図 5 から, 弾性変形段階では, 結晶粒毎に平均高度増分に違いがあるものの, 異なる負荷荷 重間でも同一結晶粒ではほぼ同じ平均高度増分を示すこと がわかる. 次に図 6 を見ると, 図 5 のように同じ平均高度増 分を示す結果にはなっていないが，弾性変形段階における平 均高度増分の大小と塑性変形段階のおける平均高度増分の 大小が対応していることがわかる。

\section{謝辞}

本研究の一部は，三井造船（株）との連携研究の一環とし て実施した.デジタルホログラフィック顕微鏡の使用に際し ては，（株）デジタルマイクロシステムズ谷田俊和氏と（株） 瞢テクノロジー松田知足氏に御協力を賜わった。 ここに，感 謝の意を表する.

\section{文献}

（1）多田直哉, 清水一郎, 八木伸曉 : 日本非破壊検査協会平 成 21 年度春季大会講演概要集, (2009), pp. 107-108.

(2) 西川出 : 非破壊検査, Vol. 54, No. 3 (2005), pp. 132-138.

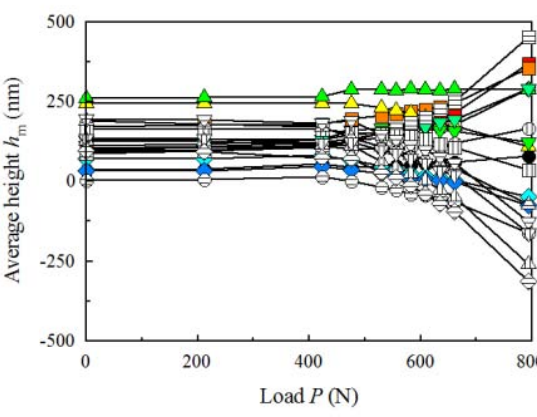

Fig. 3 Change in average height for Grains 1 to 20

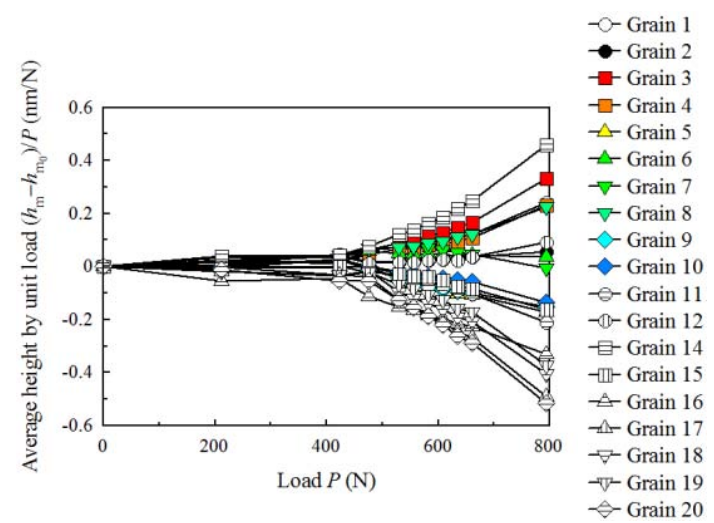

Fig.4 Relative change in average height by unit load for Grains 1 to 20

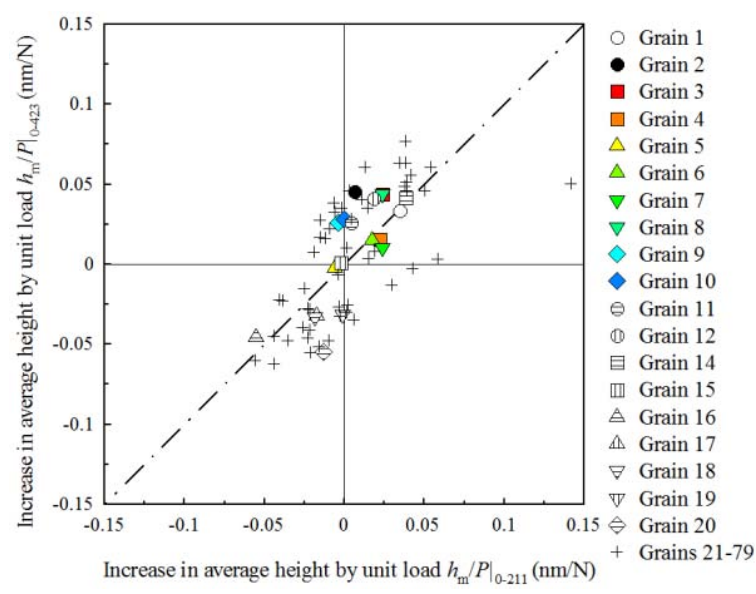

Fig.5 Increase in average height by unit load

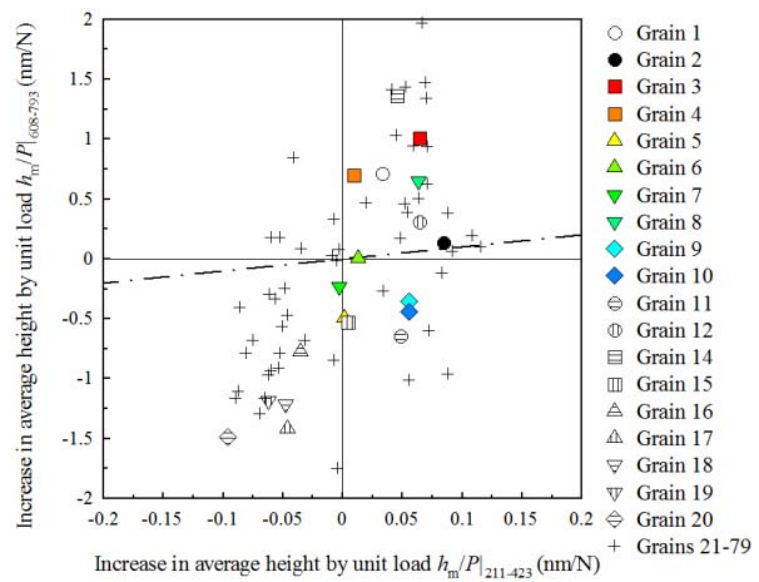

Fig.6 Increase in average height by unit load 